\section{Supplementation with folic acid and orofacial clefts}

\section{Suplementación con acido fólico y fisuras orofaciales}

\section{Dear editor,}

I read with great interest the article "Folatos $y$ Embarazo, conceptos actuales. ¿Es necesaria una suplementación con Acido Fólico?"'. It is known that food fortification and supplementation with folic acid have been effective in preventing birth defects, such as neural tube defects and congenital heart disease ${ }^{2}$. Another important point is the potential preventive role of folic acid in orofacial clefts. This has been a controversial subject in the literature.

However, a connection between neural tube defects and orofacial clefts has been discussed. In this case, their times of occurrence during embryogenesis, their status as defects as well as the related genetic aspects have been key points to understand this issue. On that basis, some similarities between this two malformations have been established ${ }^{3}$. Such data, in turn, support the theory that acid folic can likewise prevent orofacial clefts.

It should be noted, therefore, that orofacial clefts result from interaction between genetic and environmental factors ${ }^{4}$. Moreover, they occur during the embryonic and early fetal periods ${ }^{5}$. Thus, taking into account the influence of the environment factors (eg: vitamin de- ficiency during pregnancy $)^{4}$, the supplementation with folic acid during periconceptional period and first trimester of pregnancy could have an important role in preventing orofacial clefts. What do the article authors (Folatos y Embarazo, conceptos actuales. ¿Es necesaria una suplementación con Acido Fólico?) think about it?

Keywords: Cleft lip; cleft palate; folic acid.

Marcos Roberto Tovani-Palone ${ }^{a}$ ${ }^{a}$ Hospital for Rehabilitation of Craniofacial Anomalies, University of São Paulo, Bauru, Brazil.

\section{References}

1. Castaño E, Piñuñuri R, Hirsch S, Ronco AM. Folatos y Embarazo, conceptos actuales: ¿Es necesaria una suplementación con Acido Fólico?. Rev Chil Pediatr. 2017;88(2):199-206.

2. Tovani-Palone MR. Diet, adolescence and pregnancy versus folic acid supplementation. Rev Chil Pediatr. 2016;87(2):150.

3. Wehby GL, Murray JC. Folic acid and orofacial clefts: a review of the evidence. Oral Dis. 2010;16(1):11-9.

4. Tovani-Palone MR, Saldias-Vargas VP. Factores genéticos y fisuras orofaciales no sindrómicas. Rev Fac Med. 2016;64(2):381-3

5. Pang J, Broyles J, Redett R. Cleft lip and palate. Eplasty. 2013;13:ic25. 
Response to the letter of editor entitled: Supplementation with folic acid and orofacial clefts by Dr. Marcos Roberto Tovani-Palone

Respuesta carta al editor titulada:

Suplementación con acido fólico y fisuras orofaciales

We completely agree with Dr. Tovani-Palona that an "adequate" supply of folates (contained in foods plus supplementation with folic acid) is essential to prevent NTD and other malformations like orofacial clefts. We think that the concept "adequate" should have considerations in terms of the period of use and in terms of concentrations that have to be optimal. It is important to follow the current advice for pregnant women on folic acid supplementation between 4 weeks before until 12 weeks pregnancy. Additional periods of supplementation before and during pregnancy can induce epigenetic modifications in offspring genes related to metabolism with yet unknown impact on (later) health ${ }^{1,2}$.

The topic related to the optimal folic acid concentrations that are needed to prevent fetal malformations and avoid long-term pathologies in the offspring is more complex. The source of our concern is that in Chile the fortification of wheat flour with folic acid (FA) is much higher than that recommended by the United States $(2.4 \mathrm{mg} / \mathrm{kg} \text { of flour })^{3}$. In addition, Chile has a high consumption of bread by the whole population $^{4,5}$ and pregnant women are also supplemented with $1 \mathrm{mg}$ of daily FA. Both strategies are probably surpassing the upper limit established for the synthetic form of folates, defined by its ability to mask the vitamin B12 deficiency, which in women of childbearing age is around $10 \%$. Because an elevated folates/vit B12 ratio has been associated with several health impairments ${ }^{6,7}$, a balanced ratio is very important to achieve, not only by supplementation but also by supplying an adequate amount vitamin B12 needed to maintain the correct functioning of the one carbon metabolism.

Our goal was to emphasize the importance of the interaction between these two vitamins and their effects on the body, mainly on fetal programming, but without ignoring the importance of fortification programs in reducing the prevalence of malformations like NTD and orofacial clefts.

Ana María Ronco

Laboratorio de Nutrición y Regulación Metabólica, Instituto de Nutrición y Tecnología de los Alimentos, Universidad de Chile, Santiago, Chile

\section{References}

1. Pauwels S, Ghosh M, Duca RC, Bekaert B, Freson K, Huybrechts I, et al. Dietary and supplemental maternal methyl-group donor intake and cord blood DNA methylation. Epigenetics. 2017;12:1-10.

2. Pauwels S, Ghosh M, Duca RC, Bekaert B, Freson K, Huybrechts I, et al. Maternal intake of methyl-group donors affects DNA methylation of metabolic genes in infants. Clin Epigenetics. 2017;9:16.

3. Subsecretaría de Salud Pública. Ministerio de Salud. Instituto de Salud Pública de chile. Informe. Programa Fortificación de Harinas. Santiago de Chile: 2011.

4. Hertrampf E, Cortés F. National food-fortification program with folic acid in Chile. Food Nutr Bull. 2008;29:S231-7.

5. Cortés F, Mellado C, Pardo RA, Villarroel LA, Hertrampf E. Wheat flour fortification with folic acid: changes in neural tube defects rates in Chile. Am J Med Genet A. 2012;158A:1885-90.

6. Selhub J, Rosenberg IH. Excessive folic acid intake and relation to adverse health outcome. Biochimie. 2016;126:71-8.

7. Paul L, Selhub J. Interaction between excess folate and low vitamin B12 status. Mol Aspects Med. 2017;53:43-7. 